\title{
Historein
}

Vol $2(2000)$

Heterodoxies: Constructions of Identities and Otherness in Medieval and Early Modern Europe

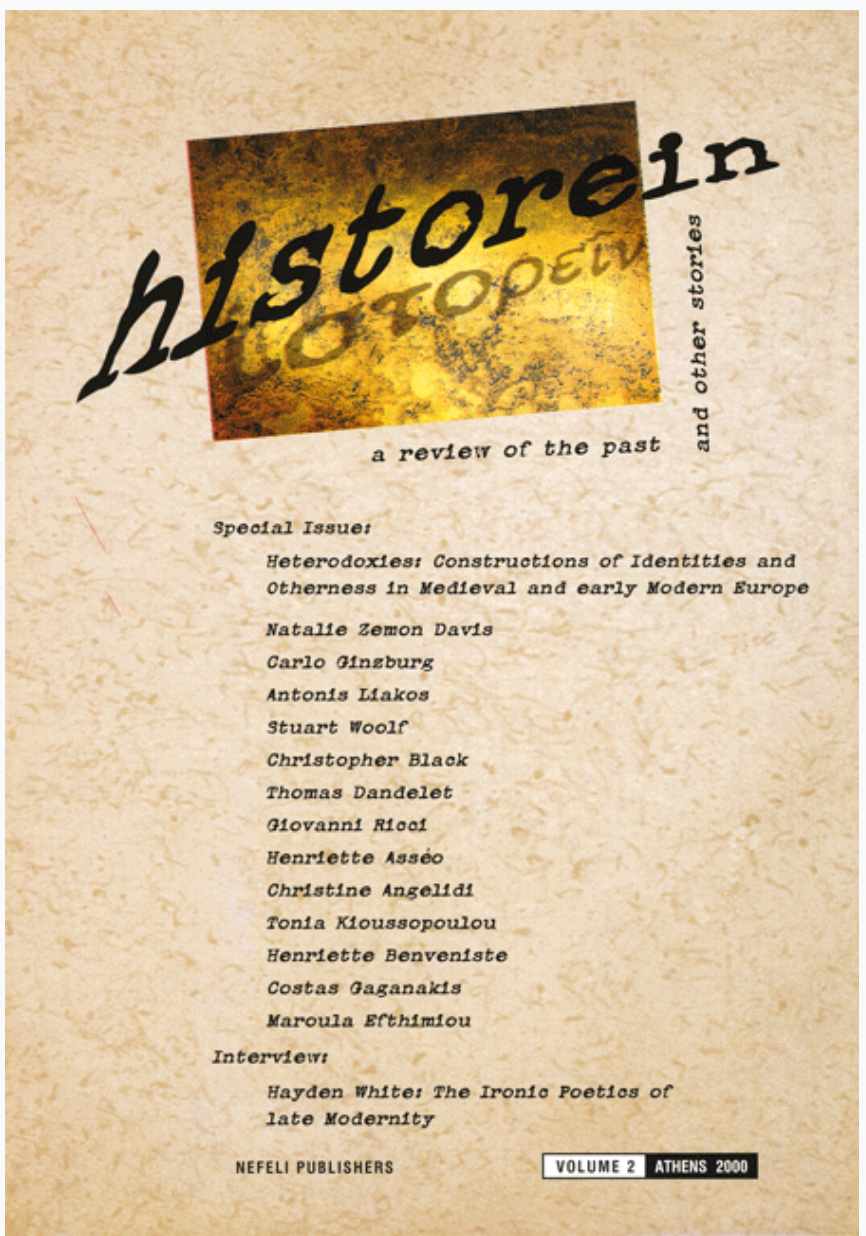

\section{Early Modern Italian Confraternities: Inclusion and Exclusion}

Christopher Black

doi: $10.12681 /$ historein.113

Copyright ( ) 2012, Christopher Black

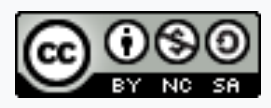

This work is licensed under a Creative Commons Attribution-NonCommercialShareAlike 4.0.

\section{To cite this article:}

Black, C. (2001). Early Modern Italian Confraternities: Inclusion and Exclusion. Historein, 2, 65-86. https://doi.org/10.12681/historein.113 


\section{Early Modern}

\section{Italian}

Confraternities:

\author{
Inclusion
}

and

\section{Exclusion}

Christopher F. Black
Lay confraternities were primarily concerned with relationships between the living and the dead, spiritually and physically, in preparation for the afterlife. But they were also important organizations in lay society, bonding people beyond the family and kinship systems. Brotherhood (and sisterhood) implies an embracing protecting relationship, as well as an alternative or additional identity. My paper is a hybrid in relation to the ambiguous title and subtitle of the Seminar! It hovers around "identities" and "heterodoxies", in discussing who might or might not identify with a particular confraternity; as well as (in part of the discussion) whether membership of a sacrament fraternity guaranteed orthodoxy. It takes up some points I made a decade ago about two rather different tendencies in the expansion of confraternities from the fifteenth century.' Some types of confraternity sought to remain exclusive, or become more exclusive, as protective societies ready to exclude the socially, politically and possibly religiously, unwelcome. Other fraternities-especially under the impact of Catholic reform movements-were ready to embrace a wider society, and become more outward looking with good works. The reforming policy of encouraging parish-based fraternities, more tightly controlled by clerics, created various problems and tensions. My paper looks at various issues, such as: female identity in confraternities; confraternal identity for certain occupation groups or orders in society; confraternities as guarantors of orthodoxy; and tensions and complications when under the impact of Catholic reform parish churches sought to include many parishioners in parochial fraternities. Whereas before confraternity brothers and sisters might make the 
decisions over how a confraternity might reflect their identity, or add an another identity, the new clerical pressures might seek to mould the members and destroy the boundaries of identities. If the broader body of the fraternity seemed too inclusive, inner exclusive groups might then be formed.

\section{Introduction}

Lay confraternities were and are associations of people coming together under written or implied rules to promote their religious life in common, primarily with a view to promoting the salvation of the soul hereafter. Of distant medieval origins, they had taken on many different names and guises by the fifteenth century. Italy-especially northern urban Italy-had a greater variety of confraternities than elsewhere, and most probably functioned more regularly throughout the year than those noted just for Pentecostal feasting and a single charitable gesture as in parts of France, Switzerland or England. ${ }^{2}$ By the fifteenth century the Italian fraternities might be broadly divided into those that were primarily flagellant, those known as Laudesi companies (with processional singing), those that were hospice/hospital-centered, others particularly dedicated to the Virgin; but there was much cross-dressing between these categories. While some were closely linked to the parish church, most were not-being either independent of clerical attachments, or linked to the Franciscan and Dominican Orders. While most were male-only, some were well mixed sexually, and a very few were female-only (though this category was to expand); some, especially in Florence, were for male youths only. Membership might vary from a handful to maybe near a thousand; with active participation on a regular basis being highly variable.

The confraternity scene changed again from the fifteenth century. In the last decade the Genoese originating Divine Love group did much to promote new philanthropic or eucharistic concerns. Venice launched a range of Holy Sacrament fraternities, and then helped promote the Rosary cult (partly aided by some entrepreneurial Germans selling high quality amber beads). The crises of the Italian wars, plagues, famine, and syphilis led to a whole range of more outward looking philanthropic societies, and associated institutions. Catholic reforming bishops led the call for parish-centered fraternities to improve Christian society under clerical leadership; a campaign that was to be taken up by the Council of Trent and subsequent Tridentine reformers. The Jesuits and Capuchins in particular joined to promote more confraternities in the wake of their missionary and educational campaigns. Under the combined efforts of bishops and orders, the confraternity networks penetrated more effectively into southern Italy, and remoter rural areas elsewhere; or at least they now produced records surviving to show their existence.

\section{Exclusive and inclusive}

In my book on Italian confraternities I suggested that in the sixteenth century there were two somewhat conflicting trends-towards exclusiveness and towards inclusiveness.

The trend towards a more status-seeking society, especially the emphases on nobility and 
gentlemanly behavior and status in the sixteenth century, could encourage further exclusivity, hence the popularity of "noble" confraternities, or philanthropy for the poveri vergognosi, the shame-faced poor (who were not necessarily noble or elite)-a topic to which Giovanni Ricci contributed influentially some years ago. ${ }^{3}$ Contrarily, the pressure of Catholic reformers and Tridentine legislators to have more confraternities based on the parish churches (and controlled by parochial clergy) should have encouraged a social mix, a kind of inclusiveness. For various reasons I have decided to revisit these problems, and explore some of the complications, particularly with information from, and thoughts about, recent publications, and a preview of some imminent articles. ${ }^{4}$

A number of questions and hypotheses about inclusiveness and exclusiveness of different fraternities can be covered in terms of statutes, and some general in-house records of meetings, decisions-made, etc.; but finer points should depend on knowing who were members, how active they were, and what they did outside the fraternity or sorority. I should emphasize that full membership lists of confraternity members are hard to find, and difficult to use readily if so found. Those who do consider membership may know something about the dominant officeholders, and know when members of the elite are involved, but be able to tell little about social and participatory levels of the other surnameless men and women, as Lorenzo Polizzotto's forthcoming work on the Florentine youth confraternity of the Purification of the Virgin will demonstrate. $^{5}$

\section{Gender factors}

There were divergent views as to whether females could be fully included in confraternity life, be members at all, or have a separate identity in their own sororities. Surviving documentation has been unhelpful here, as in much of women's history. As Giovanna Casagrande wrote in 1994, it was only finally being recognized that a fair number of women were involved, even if with minor roles. Richard Mackenney has joined her in arguing that they probably have been undercounted-and points to the fourteenth century statutes of two Venetian scuole that state: "in each chapter the sisters are not named as the brothers are, so as not to multiply too many words." 6

I have little doubt that the numbers and proportions of women who were involved in confraternities increased from the late fifteenth century, notably through the development of parish based companies of the Rosary; some of these like others dedicated to St Anna or Sant'Orsola might in fact be female-only sororities. While that might have been important for increasing the activity of women in society, enhancing their roles and status, it could have encouraged the male exclusivity of other fraternities (such as the Sacrament ones), which might have been much more dominant. Misogynist attitudes could explicitly appear: the 1569 statutes of the "politically incorrect" San Giovanni Decollato of Faenza put women along with beasts in a clause excluding them from the premises of the fraternity. While many brotherhoods were more 
welcoming, they might confine female membership to relatives of the male members; or if taking on more, restrict their involvement, and certainly restrict their roles as office-holders. Some brothers, like those in San Frediano, Florence were afraid of the women as gossips.

Flagellation or "discipline" could be a reason for excluding women totally. Many Umbrian statutes of the fourteenth century argued that their active presence might be seen as provocative, and women should be shunned like the plague. ${ }^{7}$ But some discipline confraternities did admit women. The discipline fraternity of Bergamo allowed women to join in 1336, provided they had the approval of husbands (or fathers and brothers if unmarried); they could participate in prayers, in alms, and in funerals; but the 1459 statutes made it very specific that they could not "far disciplina." All spiritual benefits were open to them. ${ }^{8}$

Discrimination against full inclusion proved detrimental. In Bologna female membership increased from the fifteenth into the sixteenth centuries but fell again, when the women faced exclusion from office-holding and serious responsibilities, were met by misogynist fears of the Temptress in the midst, and were deterred when active flagellation was revived. ${ }^{9}$ In 1547 Lucia Bolza led a notable protest against the diminished roles of women in Bolognese confraternities, and especially Santa Maria della Pietà. Nick Terpstra suggests that this was stage-managed, and that the net result was to appear to be inclusive and give them more prominence but in practice to put them under patrician male social control. In the sixteenth century discrimination within mixed fraternities could lead women to form their own exclusive sororities, with Marian devotions; the new climate encouraged this, though they would not probably escape strong priestly supervision. But a new use of economic power and financial resources gave women in some Umbrian towns like Assisi, Gubbio and Todi a certain leverage. To fortuitously emphasize this issue, as I was completing this paper an art historian revealed that a hitherto unknown female-only confraternity (the Company of the Virgin Annunciate), in the Tuscan town of Fucecchio commissioned in 1521 a splendid Nativity altarpiece from the Florentine painter Giovanni Larciani (the now unmasked "Master of the Kress Landscapes"). ${ }^{10}$

The expansion and reform of Roman confraternities from the late fifteenth century brought an increase in female membership. Though enrolled primarily for spiritual participation (as in Santo Spirito), sometimes women could have prominent roles and have their own relevant officials. Women in the Santissima Concezione specialised in dowering poor girls. In the Annuziata women were additionally prominent in visiting the sick. Anna Esposito argues that at the turn of the fifteenth-sixteenth centuries, women in Roman confraternities had a higher profile than women in other cities. One can also note a bid to include women from elite families, possibly for patronage reasons. ${ }^{11}$

The female presence might affect the devotions and attitudes of males. Jennifer Rondeau has suggested that their presence in some Laudesi companies (from the fourteenth century), 
significantly affected the complex gender aspects of the Laude, as in prayers to the Virgin and Christ; that this altered the homosocial bonds of male societies, and that into the fifteenth century they influenced confraternal campaigns to promote peace in society. ${ }^{12}$

\section{Confraternities and Guilds}

One of the obvious areas of confraternal exclusivity was that where trade or craft guild and confraternity more or less overlapped. In the broader history of European guilds and fraternities there has been, and is, considerable confusion. Many medieval and early Renaissance confraternities would have been predominantly artisan in membership; and given the concentration of particular crafts in certain locations, a fraternity might be dominated by one major activity, thus having a mixture of religious, welfare and "trade union" activities in one body-with the last element a potential worry to the elites, as with the Florentine wool trimmers in the early sixteenth century, or various Neapolitan occupational groups later. ${ }^{13}$

Membership of an economic guild (itself often mandatory for the pursuit of the craft) could mean compulsory involvement in a religious fraternity and paying dues-as sometimes in Genoa, Rome or Venice. ${ }^{14}$ In Venice most trade and craft guilds (arti) had a related confraternity (scuola), to which guild members should belong unless they also belonged to another arte and its scuola (multiple membership of guild and confraternities being possible). However, it is often difficult to distinguish between the "compulsory" arte-scuola, and the devotional scuola that happens to have a predominant type of membership, as the work of Richard Mackenney has in particular shown.

In Venice the scuole piccole developed first through the economic guilds; but in 1247 we find statutes setting up a scuola, San Mattio on Murano, that was divorced from a trade. ${ }^{15}$ This was to lead to many devotional scuole piccole that were not formally trade or craft based, suggesting the development of separate economic and socio-religious groupings for consolidating identities and networking organizations. But this picture of separate identity becomes murky. Perversely the abovementioned San Mattio scuola later came to be dominated by jewellers and goldsmiths, and they used it as one of their networking bases. The mercers came to dominate a number of scuole of various kinds, starting with one in San Giuliano. Later they had the Scuola di San Teodoro near the Rialto as their main scuola for high profile processional activity and social-political domination. They secured its elevation to the status of a Scuola Grande in 1554. Subsequently mercers were also the leading group establishing the Scuola del Santissimo Rosario in 1574 in the prestigious Dominican church of Santi Giovanni and Paolo, providing a splendidly decorated chapel to celebrate the naval victory of Lepanto over the Turks in 1571. A rival social-economic group, the ironmongers, largely dominated the Scuola di San Lorenzo. Other groups of people with a common activity might come together for mutual protection and devotion through a scuola, such as the fish sellers at San Nicolo, probably, because of the associations of the patron saint; or the cripples who in 1392 formed the Scuola della Beata Vergine Annunciata dei Zotti. The boatmen who operated the ferry [traghetto] at Santa Margherita formed the Scuola di San 
Vettor for themselves there.

Venice seems to have been unusual in continuing foundations and re-foundations on these lines (along with all the other kinds of scuole); but then its guild system remained unusually powerful, vibrant and flexible well into the seventeenth century. Other Italian cities, including Milan, Rome and Genoa up to the sixteenth century, had similar confraternities closely if not exclusively linked to commercial, craft or occupational activities. The Genoese innkeepers created their own confraternity in 1600, and music teachers theirs a little later. In Rome the fraternity of Santa Maria dell'Orto brought together a combination of artisans and sellers in the Trastevere district, under the cult of the Madonna; and it established a notable hospital for them. Painters, engravers and goldbeaters formed themselves into a guild-confraternity of San Luca, which eventually helped create the academy cum confraternity of San Luca in $1593 .{ }^{16}$ My sampling of late seventeenth and eighteenth century Roman guild records suggests that some groups-such as the masons [Muratori], the woolworkers [Lanari] the Bombardieri of Castello Sant'Angelo, and the coffee sellers [Caffetieri] continued to have a significant religious and welfare dimension, for themselves-as well as for condemned prisoners, by exercising privileges to request release from execution or the galleys. ${ }^{17}$ The confraternal protective cloak, covering religious devotion, social welfare, commercial protectionism or networking could persist through the centuries; a sense of common identity in a competitive world must have been significantly reinforced.

There were of course other artisans who had their exclusive identity as part of an economic group -the guild in the narrow sense-and would have another identity as part of a totally different religious association, for example in a parochial Sacrament or Christian Doctrine fraternity, or the Jesuit-influenced Pieta dei Carcerati dealing with Roman prisoners, which might include many layers of society, as discussed below.

\section{Status and Occupational Consolidation}

If such people of the middling sort wanted their own exclusive fraternities, so did some of the upper orders of society. The tendency across the later fifteenth and sixteenth century to stress nobility and gentility in a process of aristocratization encouraged the formation of some exclusive fraternities. Naples had, for example, the nobleman's Venerazione del Santissimo Sacramento, and the Devote di Gesù for noble women only (founded 1554). Genoa had two noble Della Morte companies, though Edoardo Grendi noted a more general willingness of Genoese patricians to enter socially-mixed fraternities. ${ }^{18}$

The Jesuits encouraged separate confraternities for different status and occupational groups (though they also sponsored and advised more socially mixed fraternities). In Lecce the Jesuits organized five fraternities for nobles, scholars, students, youths and artisans; Perugia had three based in separate oratories in the one Jesuit church: nobles (which probably would have included scholars, given the way Perugia University was developing), artisans and contadini. As the Jesuit 
interest in education developed, so they targeted students as a group to be fostered through exclusive confraternities.

Ignatius Loyola himself established a tendency to encourage noble involvement in philanthropic work for all, but organized out of exclusive noble fraternities, when he founded in the 1540s what was to become the very obviously exclusive Archconfraternity of Twelve Apostles [Archconfraternita de' Santissimi Dodici Apostoli]. ${ }^{19}$ The Casa di Santa Maria was launched in 1541-2, primarily as a refuge for married women in difficulties, and was administered by a confraternity of noble or higher clerical men, and noble women [Compagnia della Grazia]. The foundation membership lists featured men and women from the Colonna, Orsini, Farnese and Della Rovere family, the wife of the Imperial Ambassador (Eleonora Osorio), and Cardinal Rodolfo Pio da Carpi, with another 14 cardinals, seven archbishops or bishops. How active they were is unclear, but presumably their name gave prestige to the work of those who actually ran this institution and encouraged the foundation of other similar rescue houses. Eleonora Osorio took the idea to Palermo when her husband moved there as Viceroy. Noble women were seemingly the most active members. Social exclusivity in their case in particular probably made it easier to be influential contributors to social welfare. ${ }^{20}$

At the other end of the social scale there were recognized confraternities for the disadvantaged (as well as the less legal fraternities of vagabonds and con-men). Milan had its Scuola di San Cristoforo for the blind and other invalids from 1471; Cardinal Carlo Borromeo was to improve its religious activity and prestige in his reform of statutes in 1569. Venice had a Scuola degli Orbi for the blind, and since 1392 the Scuola degli Zotti for the invalid. This latter was in one sense inclusive, in acting as a facilitator for foreign beggars to enter and settle in the city-to the annoyance of the Health Officials [Provveditori della Sanità], who in 1542 sought to tighten their control over this group. Such fraternities were a way of recognizing the rights of certain people to beg (when otherwise this was illegal or severely restricted), and give some social and religious solidarity-though I know of no study of how they operated as confraternities. Paul V in 1613, in a climate hostile to begging, founded the confraternity of Sant'Elisabetta (also called Della Vergine) to sanction and sanctify begging by crippled men and women. ${ }^{21}$

\section{National Confraternities and Assimilation of Immigrants}

The larger Italian cities had large immigrant groups and were socially fluid. National confraternities were an obvious way of providing newcomers with spiritual but also social and physical support, and a separate identity, whether for a short term stay or as a way of integrating into the city. They could confusingly overlap with the student "nations" in university cities like Bologna or Perugia. There were the obvious "national" fraternities for both narrow geographical sources, or wide groupings: for Lombards, Bolognesi, Florentines, Brescians, Neapolitans, etc.; or for French, Flemings, Spaniards or Germans; the "Germans" in Perugia might include Bohemians and Hungarians. Venice had its famous Scuole for Greeks and Slavs, with splendid 
oratories and churches, and lesser fraternities for Albanians, Tuscans and Lombards. Rome developed the largest collection of national fraternities, often with hospitals and hospices; nine at least by the end of the fifteenth century, twelve added in the sixteenth, six in the seventeenth. This is explained by the considerable overall expansion of the city, by the extra "need" for such societies because of short-stay pilgrimage traffic, and possibly for the seekers after privileges, concessions, clerical patronage, and legal redress who might stay a little longer. For this sort of fraternity there was exclusiveness in terms of geographical origin, possibly social and religious custom; there would be social inclusiveness in that (if briefly) aristocrats, merchants, students and beggars would intermingle, with the latter seeking help from the former. Tom Dandelet's work on the Spanish confraternity of the Most Holy Resurrection, and wider Iberian contingents in and around Rome, is giving us a better insight into this type of fraternity. Some of the national groupings that started by cushioning incomers became very well established, and central to the religiosity of Rome-most notably the Florentine brothers of San Giovanni Decollato, specialists in escorting condemned prisoners, and builders of a finely decorated Oratory. They then were inclusive of non-Florentines-but possibly excluding the kind of poorer and less intellectual brother of the earlier period. ${ }^{22}$

Some of the national fraternities interlocked with commercial and trading interests. The fraternity of the Norcini in Rome was almost certainly primarily for those from Norcia who provided the city with pork and salami (though having to compete with the Pizzicaroli pork-butchers); but a few Norcini might have been specialists in preparing budding singers aspiring for careers as castrati. ${ }^{23}$

In Venice German cobblers and shoemakers were allowed to establish their own arte-scuola [Callegheri e Zovattini Tedeschi]. Such German immigrants, often from Lutheran lands, could not open a shop [bottega] unless they joined the scuola. In 1588 denunciations to the Inquisition indicated much trouble within and outside the scuola; including standard accusations about eating meat on Fridays and Saturdays (including Good Friday) and other feast days, but also conflicts between members and their wives, and non-member neighbours. The somewhat confused evidence from the surviving record reveals problems of assimilation into Venetian society, the tension between religious practices, tensions with more "Venetian" neighbours, but also some intermarriage with non-Germans. In other words we are again on the borderland of inclusiveness and exclusiveness. One of the leading accused was Martin de Luca, cobbler [calegaro], originally from Graz under Archduke Carlo. He had been in Rome at one point for six months (connected it seems with the confraternity hospital of Madonna dell'Orto), but in Venice since the plague (1577). In squirming around over accusations of eating meat at improper times, he admits to so eating in the house of a porter in the German merchant area [ligador del Fontego], who "argued that God gave us to eat anything; when young I believed that without sin one could eat meat on Saturdays, but for six years I have confessed and communicated, and have known it is a sin." In his defence there are registered testimonials, fede, not only from the parish priest (pievano) at San Samuele, and a confessor at San Moise, but also from the nunzio of the Holy Sacrament confraternity in San Samuele, to the effect that he had paid his dues for 
the parish feast, as a brother of the scuola the previous August. This would suggest he was trying to integrate himself into a fully orthodox Catholic environment. ${ }^{24}$

Another Venetian Inquisition case might be aired again to highlight problems of the roles of fraternities in protecting foreign artisans, offering comfort to them as immigrants, social and economic networks, but rendering them suspect to neighbours or higher authorities of church and state. There was a scuola of Florentines dedicated to San Giovanni that met in the Frari. In 1590 a certain seller of serge cloth at the Sign of the Lion in the Calle della Rassa, denounced this group for participating in night meetings when they said prayers: they flagellated, and in turns discussed the Gospel-in the dark. This was all in the chapel next to that of the Jesuits (to whose scuola the delator seemingly belonged). In testimony it was alleged that there was another scuola meeting at San Polo, headed by a Florentine, that met at night also to discuss the Gospel-without a priest. The Inquisitors did not pursue the matter. How much the denunciation was governed by religious zeal, influenced by the Jesuits, or by Venetian-Florentine rivalry remains unclear. Florence itself had a certain type of fraternity, the buca, which met at night for flagellation sessions in the dark. ${ }^{25}$

Another problem of assimilation, and the role of confraternities, arises with a third Venetian Inquisition case, concerning a Jewish convert. A few months ago, Anthony Molho talked in Glasgow about the experiences of Jews moving through the Mediterranean in the sixteenth to twentieth centuries, through five case studies. He started with Gaspar Ribeiro, whom Brian Pullan had brought to our attention, along with Abraham Righetto, as a rudderless marrano in the 1570 s, trying to synthesise two faiths; and who died while under investigation by the Venetian Inquisition in 1581. Molho looked at him from the viewpoint of the complaining rabbi, who argued that no marrano-Jewish convert to Christianity could settle on one, but was destined to move unhappily between the Jewish and Christian faiths (which if they were travelling merchants and dealers through the Mediterranean, they might well do many times). In my book I had looked at Gaspar from a different perspective: as a convert torn between the pressures of a son (João or Giovanni) who wanted to be with the Jews, and a daughter (Violante) who wanted to be Christian and was anti-Jewish. I saw-and still see-Gaspar as finally making a commitment as a Christian, and being accepted and assimilated into the parochial community, by joining a parish Holy Sacrament confraternity, serving as its gastaldo; paying for the decoration of its chapel, lending hangings for feast-day celebrations, carrying a candle behind the host on Good Friday, and especially by commissioning and paying for an expensive tabernacle for the Host. For Molho this was just more dissimulation, necessitated by the religious attitudes. To me that degree of commitment to a Sacrament confraternity and its veneration of the Host marked finally a true commitment (certainly after money-making and life-saving deviancy), and inclusion into the Catholic faith and society (stilo veneziano). ${ }^{26}$

In another view of exclusiveness, Vincenzo Paglia produced the interesting but contentious argument that some Roman confraternities in the sixteenth century became agents of new 
capitalists, predominantly from northern Italy, who needed a comparatively exclusive organisation that would help them battle against the entrenched clerical-dominated society, and allow them space to be active. They could use the philanthropic activities of some confraternities to give them roles in society, and maybe salvation of their souls. Paglia focused on the Pietà dei Carcerati, which looked after prisoners and prison life. Unfortunately, as I have pointed out before, he could not provide a full indication of members to prove his class-based case. From his own scattered examples of individuals it appeared that the Pietà was an interesting mix of immigrants and more long-standing inhabitants; and occupationally could include barbers, joiners, turners, shoemakers, painters, a bookseller at the Chiesa Nuova (immigrant from Savona), and up the social scale as well, to advocate, physician, maestro di casa for the Rinuccini nobles, the bishops of Florence and Alisso, and a Signora Abalante from the Counts of Corbara family. This causes me to doubt Paglia's class argument; but also to suggest that this was a useful mechanism for assimilating in-comers with the broader society, and providing them with a social role in Rome. ${ }^{27}$

\section{Catholic Reform, Tridentine reform and Parish confraternities}

I turn now to the problem of parish confraternities in the era of Catholic Reform. Here the debating issues are the extent to which confraternities helped bond the laity of all social classes within the parish and the extent to which they created new exclusive groupings within the parish.

Given the medieval and renaissance position where lay confraternities had considerable autonomy, reforming episcopal leaders were often wary of encouraging the development of confraternities. But early Catholic reformers like Giberti of Verona were followed by Tridentine reformers such as Carlo Borromeo and Gabriele Paleotti in encouraging fraternities, provided they were under episcopal supervision, and based in the parish church under the parish priest or his assistants. For brevity's sake, I suggest that the ideal might have been an inclusive one, with a variety of fraternities embracing, but controlling, most permanent members of the parish. Holy Sacrament confraternities would embrace the more dedicated male parishioners, assisting the priest, possibly acting as a vestry and fabric committee. A Rosary fraternity would cater for mainly women parishioners. A Name of God fraternity [Nome di Dio], of male and female members, would help promote peace in the community; a mixed gender Christian Doctrine society helped to teach children and co-ordinate the more literate parishioners. These and other philanthropic brotherhoods might include the socially deprived through spiritual and physical charity. This ideal way would bond most of the community. Of course the ideal was seldom met, and such an inclusive ideal had potentials for exclusiveness and tension. Unless an active parish priest encouraged Pauline harmony through diversity, multiplicity might breed tension-between social or godly elites and the broader parish, between male and female, between the primarily spiritual and the primarily philanthropic. A chapel in a parish church might be a suitable base for a confraternity that, however, had interests cutting across parish boundaries. There was plenty of room for tension between priest and lay brothers and sisters over who dictated terms. Clerical 
superiority could not be assumed, especially if confraternities had significant roles in financing and decorating the church and its chapels.

Here I would like to point to a few problems ahead of the (delayed) publication of a lengthy article on parish-confraternity relations, using some new and old examples. ${ }^{28}$

An open inclusive Sacrament fraternity, encouraged by bishop and parish priest, might end up being a dominant lay elite, as in the Bologna parish of Santi Vitale e Agricola with the mixed-sex Sacrament confraternity launched by Bishop Paleotti in 1566. It started with a good male-female balance, and wide social mix, having its own meeting rooms, and helping the clergy over Sunday school teaching. By the early seventeenth century its officials seem to have had a major elitist role in controlling church appointments, running the poor relief system, and organising the FortyHour, Quarantore devotions. ${ }^{29}$ Ordinary parishioners might resent such elite fraternal leadership. In 1573 on the Venetian island of Sant'Erasmo the ordinary parishioners, gardeners and servants, noisomely showed their resentment against the exclusive Sacrament Scuola when it highhandedly delayed a procession for the feast of Saint Luke-by scattering the processional route with unseemly refuse! ${ }^{30}$

Friction between parish priest and fraternity might easily develop, and one party might well resort to law over jurisdictional rights and obligations. The priest might complain that fraternities were not paying their dues, not revealing their accounts, not obeying orders about processions, etc. Fraternities complained that the parish priests or curates were not turning up for funerals, not saying the masses for the dead as obligated, not visiting the sick. A friend and former colleague has provided me with an excellent example of a long contract between parish clergy and a Venetian confraternity, designed to resolve disputes. The notarised agreement was drawn up in 1604 between the guild fraternity, scuola, of second dealers (arte degli Strazzaruoli), and the clergy of San Zulian, where for long the scuola members had celebrated masses. There had obviously been a long-running battle, with the impression that the parish priest [piovano] and assistants [titolati] had neglected the fraternity's spiritual needs. It was agreed there should be a celebration of a mass each Monday for the company, finishing with a De Profundis and prayers due for departed members. There should also be sung masses for the eve and feast day of St. James Major (the fraternity's patron saint) and sung vespers with organ on his feast day. The scuola was to be free to hold general assemblies at will and be able to store in the church what it required. The clergy would have a commemorative sung mass soon after All Souls' Day. In return the contract stipulated what the scuola had to provide for the parish clergy in the way of candles and money payments for the above celebrations, and for every funeral. This was a specialist arte-scuola, drawing brothers and sisters from across Venice, and not a parochial or neighbourhood scuola. Its presence must have complicated the life of the parish, and not contributed to parochial inclusive harmony. It should be stressed that the guild-fraternity of second-hand dealers embraced fairly well-to-do masters dealing in expensive cloths and furnishings, as well as peddlers, and they dealt with rich and poor clients. One should not assume 
(in a reflex reaction to "second-hand dealer") that the parish clergy were disdaining undesirable men and women on the fringes of society; but they might not have wanted such a mixed group from all over Venice being too demanding in the parish church. ${ }^{31}$

As an example of a parish priest resenting a selfish and domineering fraternity impeding on the parish and church, we have the seventeenth century Pisan priest, Andrea Tommeucci. He reported in his Ricordi that he had told the confraternity of shipworkers (Arsenalotti), who had a chapel in his parish church, that they had no jurisdictional rights; he would only fulfil a specified number of masses-the Mass for the Dead, and six masses for each dead brother. He was not going to celebrate at the whim of each brother, and he would not let them use another priest to celebrate in his church. ${ }^{32}$

A complex situation that illustrates a number of relevant problems of parish-fraternity, lay-clerical relations, is found in the history of Rome's large central parish of San Lorenzo in Damaso (bordering the Piazza Navona). It had about 5000 parishioners in the eighteenth century. A number of fraternities were based in this church, with varying relationships to parish and clergy. An early sacrament fraternity, started in 1501 under Giles of Viterbo's influence, became notable as a mixed gender society, taking the sacrament to the sick, distributing alms, and dowering poor girls. Membership was largely artisanal, but not confined to the parish. It had its own chapel, own chaplains and did not rely on the parish priest, though its rich accoutrements were entrusted to the sacristan for safe-keeping. ${ }^{33}$ By the eighteenth century its inclusiveness in caring for the poverty-stricken parochial poor was shared by other fraternities in the church such as the Immaculate Conception and the Soccorso. The Soccorso dei Poveri had been established in 1602 by a very active parish priest (Felice Veronici); though its full congregation numbered about 40 lay men and clerics, it was-at least for the first 25 years I was able to study-a small dedicated elite group working closely with the parish priest. It was involved in organising Christian Doctrine teaching for the parish, in arranging Forty-Hour devotions, but primarily it allocated money to the poor, and was doubly charitable in paying poor widows to bring up and educate orphaned children. ${ }^{34}$ Philanthropy was primarily for the regularly resident parish poor, though strangers were helped-such as German patients in a nearby hospital, or a young dying English girl. ${ }^{35}$ This harmonious, embracing charitable picture, was marred by the fact that the College of Confessors, also resident in San Lorenzo, challenged the Soccorso's role in choosing the poor to be helped. In a 1628 intervention the titular Cardinal of San Lorenzo (and papal vice-chancellor), Lodovico Ludovisi, sided with the confessors' claims to supervise the lay fraternity's work. ${ }^{36}$ Parochial harmony was probably further complicated by the fact that, while the Soccorso might finance Quarantore celebrations, this church was also notable for far more extravagant displays desired by papal families, with leading designers like Pietro da Cortona at their disposal. ${ }^{37}$

Most parishes were smaller and less complex than San Lorenzo. My wider studies and consultations so far have suggested that, generally, confraternity-parish conflicts or disharmony increased after a "best practice" period of mutual encouragement in the second half of the 
sixteenth century: when reformers were trying to create a sensible parochial system; when the whole new range of fraternities for new and revived spiritual and social needs were being promoted by laymen, bishops and members of religious orders. Subsequently there were too many opportunities for conflict and mutual recriminations.

\section{Inner and Outer Groups. Stretta and Larga}

A socially inclusive confraternity of large membership might lose that single identity and subdivide. For some Bologna fraternities this was officially recognised as the larga and the stretta. This dated from the early fifteenth century reforms of Bishop Albergati. The larga was for the broad membership, adherence to which was not very onerous, where members could have fairly active periods, then fallow ones of limited participation. Those in an inner group, the stretta, would be expected to be more active and dedicated religiously, austere in life-style, but might also have a specialist activity, such as running a hospital. The most notable and interesting example is the formation within the confraternity of Santa Maria della Morte of the socially and religiously elite group of Comforters for the Condemned, [Scuola dei Confortatori]. Supposedly this was a Pauline approach of having many functions within an unbroken community. ${ }^{38}$ But there was not an amicable diversity in the rather similar Milanese confraternity of Santa Croce e della Pieta dei Carcerati. The combination of a parochial devotional confraternity and an exclusive group specialising in looking after prisoners proved very divisive and detrimental to both groups. ${ }^{39}$

A new example of the development of an inner exclusive group which risked marginalising the wide membership is that of the Florentine Youth Confraternity of Archangelo Raffaele, as studied by Konrad Eisenbichler. ${ }^{40}$ From the early fifteenth century the Archangel Raphael fraternity was notable for its religious plays, lay preaching (including sermons by some of the youths themselves), adventurous music, feasts and games, etc. Youths from many sectors of society could be included. But in the sixteenth century the cultural area became more "professional," i.e. over-age, professional musicians were imported, and the normal boys and youths contributed less (though clearly it was a training ground for later musical achievers). Eventually it turned into a fully adult fraternity. The fraternity performed plays by one of the leading playwrights of the day, Gian Maria Cecchi, and music by such famous innovators as Jacopo Peri and Marco da Gagliano. This also encouraged elitism in terms of the social composition of its intake, and its patronage links. From time to time an inner group, a stretta, of the elder and more dedicated members was developed, as the overall membership grew, though this did not have the full effect of marginalising the wider membership (Iarga) as in some Milan and Bologna cases.

\section{Discipline and Control of Membership}

Exclusion and inclusion should of course take us to a consideration of enrolment and expulsion policies. As I pointed out in my book, statutes could be fulsome in clauses dealing with whom to keep out (blasphemers, adulterers, usurers, sodomites, gamblers, tavern addicts, card-players, 
people who behaved violently); otherwise open fraternities might exclude certain types of government officials, as did the Florentine Della Misericordia, and Sacrament company at San Felicità; or in the rules of Bologna's stretta of Buon Gesù: singers, actors, magicians, and practising Jews (an interesting thought in 1520). ${ }^{41}$

Once a member however, as I showed, it was quite difficult to expel members, even when the officials had an inclination to do so. John Henderson did however point to Florence's Gesu Pellegrino as having an average-in the fourteenth century-of about $16 \%$ expulsions a year (mainly for non-attendance and disobeying officials, rather than serious moral offences). Nick Terpstra in his study of Bologna has also usefully elaborated on the problem. Often a Padre Ordinario sought to discipline or expel a brother, to find that the elected lay officials were very reluctant. The laudesi companies were almost invariably forgiving and ready to accept backsliders; the flagellant ones were a little more inclined to exclude. However the fraternity of SS.Girolamo ed Anna, which kept good records through the fifteenth and sixteenth centuries, did indulge in purges in both its youth and adult sections. Joëlle Rollo-Koster has recently highlighted an intriguing problem, of the extent to which members were excluded from the fraternity and its benefits after death, by having their names removed from the memorial books. ${ }^{42}$

\section{Conclusions}

I have no great conclusion or hypothesis to offer. In rethinking the way confraternities developed from the fifteenth to sixteenth century, I am now more inclined than ten years ago to see exclusiveness beating inclusiveness, particularly in more fully considering the complications of parish-based fraternities. Certainly by the end of the period more confraternities existed and enrolled more members - female as well as male-than earlier, in north-central areas as well as the (probably) fairly barren south. There was often a diversity of choice-within the parish structure, and outside it. While, especially initially under parochial reforming zeal, the new fraternities might have been inclusive in the sense of cutting across hierarchical social and gender divides, there was soon a danger that confraternities would form new inner networks: some close to the parish clergy; others hostile; some puritanical and inward looking, others looser but possibly occasionally embracing outsiders in their welfare. Elitist control of some sort was likely to develop. However we remain much in the dark, since few have tried to analyse the membership, and how the active ones operated in society in other capacities. Eighteenth century social reformers - like the historian L.A. Muratori or Grand Duke Peter Leopold - complained that confraternities impeded parochial religion through selfish interests, and if they were philanthropically active it was simply fostering idleness and creating a dependent society. If they were not socially divisive and exclusive, they were now economically damaging. A no-win situation. ${ }^{43}$ 
Addendum, June 1999.

Re: A confraternity of Florentines at San Polo, Venice, referred to above at note 25. While researching recently in the Archivio Patriarchale, Venice, and sampling criminal records, I chanced upon a file "Contra Societatem Florentinorum apud ecc.S.Pauli, 13 Julij 1590", (in the section Archivio Segreto, a volume entitled Criminalia Presbyterorum 1589-1742). This proved to be a file on the investigations (not leading to trial) following the denunciation of a San Polo company to the Patriarch's court, rather than the Inquisition (of which tribunal the Patriarch was also a member). There was a fuller investigation of this group than of the Frari one denounced to the Inquisition. The denunciation followed a fracas in the rented fraternity rooms attached to San Polo, but complaints were also made that the company discussed the gospel, having possibly read a vernacular edition of the New Testament, and that brothers performed a feet-washing ceremony on Maundy Thursday without benefit of priests. Though the membership was seemingly mainly Florentine, other foreigners were involved and some Venetians. In part there seems to have been a conflict between a Venetian element, possibly backed by a Jesuit, against the main membership which was following a more independent lay tradition derived from a Florentine confraternal model. I hope to publish a full transcript of the investigation, with commentary, to show outsider and insider views of confraternity activities, and internal conflict over proper fraternal activities in the post-Tridentine world.

${ }^{1}$ Christopher F. Black, Italian Confraternities in the Sixteenth Century. Cambridge: Cambridge University Press, 1989, p. 271: "Socially, confraternities were protective societies. Those that were socially exclusive could constitute an extended family, a way of cementing relationships and fostering peace between groups of families, much like godparenthood associations. The secrecy and codes of honour ordered or implied by the statutes sought to exclude the socially or politically unwelcome. Other confraternities aimed at social protection by cutting across family and status divisions to intermingle social groups; these can be seen as creating clientele networks and being part of a wider patronage system, as in Florence."

A preliminary trial, and longer, version of this paper was given at a Seminar in March 1998 at the Institute of Historical Research, London University. I am grateful for questions and comments made then, especially by the organisers and my hosts Trevor Dean and Larry Epstein. I am also grateful to Tricia Allerston, Konrad Eisenbichler, Richard Mackenney, Nick Terpstra, and Danilo Zardin for documentation, pre-publication material, information, comment and encouragement in various ways. A shortened version of this paper was presented at Syros. This article is a version of that paper, with marginal revisions and additions, following discussion. It largely retains the style suitable for the occasion. I am grateful in particular to Natalie Davis, Costas Gaganakis and Tom Dandelet for comments and encouragement at the Syros Seminar. Included in this talk is my usual sales pitch that confraternities provide an insight into almost all aspects of early modern Italian history - social, cultural, political as well as religious. Some detail is provided to exemplify what fraternities were and did, for the benefit of those less familiar with such societies.

${ }^{2}$ I have greater confidence in stressing Italian confraternal variety and activity having written a postlude chapter on "European Confraternities", considering the wider comparative field, for a forthcoming collection of essays on English Religious Guilds: English Guilds. Eight Regional Studies, ed. by Ken Farnhill.

${ }^{3}$ Black, Italian Confraternities, pp. 147-50, 160, 169-74. I return to the debate about who were the poveri vergognosi in my forthcoming "The Development of Confraternity Studies" [see next note]. See also Giovanni Ricci, "Povertà, vergogna e povertà vergognosa", Società e Storia, 5 (1979), pp. 305-37; Amleto Spicciani, "The 'Poveri Vergognosi' in fifteenth-century Florence", in Aspects of Poverty in Early Modern Europe. Florence: Badia Fiesolina, Publications of the European University Institute, 1981, pp.119-82; Flavio 
Rurale, "L'attività caritativa degli istituti religiosi e il ruolo della Compagnia di Gesù" in Danilo Zardin (ed.), La Città e I Poveri. Milan: Jaca Books, 1995, pp. 253-72, esp. pp. 267-72.

${ }^{4}$ Stimulus for rethinking came from being asked by Nicholas Terpstra to write a chapter "The Development of Confraternity Studies over the Past Thirty Years", for the forthcoming Confraternities and Social Order in Early Modern Italy, which he is editing (Cambridge University Press). In writing my contribution I was given access to versions of most of the articles that will be published there, some of which will be cited below. My reconsiderations here have been prompted by diverse factors connected with research interests and wider teaching preoccupations; by my own attempt to sort out the relationships between confraternities and parishes in the post-Tridentine period (discussed in section 7 of this paper). Rethinking came from Nick Terpstra's elaboration on the problems of the stretta and larga divisions within Bologna confraternities (which I had touched on in my book), in his Lay Confraternities and Civic Religion in Renaissance Bologna. Cambridge: Cambridge University Press, 1995; from reading Konrad Eisenbichler's draft for his just published The Boys of the Archangel Raphael. A Youth Confraternity in Florence, 1411-1785. Toronto: Toronto University Press, 1998; by, in a teaching context, talking about Medici networking, patronising and controlling others in the Republican period; by discussions of the "myth" of Venice, the supposed harmony of society, and lack of resentment towards the exclusive elite (with the Scuole Grandi and some scuole piccole seen as explanations); and by (most recently) Angelo Torre's revelations (in his "Faith's Boundaries: Ritual and Territory in early modern rural Piedmont", in Terpstra collection cited above), about Pentecostal Holy Spirit fraternities in Piedmont that cut across parish and other administrative boundaries and helped form and identify communities long after post-Tridentine reforms had been promulgated.

5 Lorenzo Polizzotto, "The Medici and the Youth Confraternity of the Purification of the Virgin, 1434-1506", forthcoming in Terpstra (ed.), Confraternities and Social Order.

${ }^{6}$ Giovanna Casagrande "Women in Confraternities between the Middle Ages and the Modern Age in Umbria", Confraternitas, 5:2 (Fall 1994), pp. 3-13; Richard Mackenney, "The Guilds of Venice: State and Society in the Longue Durée”, Studi Veneziani, 34 (1997), pp. 15- 43, at p.40; he cites Scuola di San Zuan Battista, ASV: Provveditori di Comun, reg. P., c.550r; Scuola di Santi Cosmo e Damiano, ibid., reg.Q., c.689r: " in ciaschedun capitoli non siano nominate le sorelle, come li fratelli per non molteplicar troppe parole."

7 Giovanna Casagrande, "Confraternities as a vehicle for women's religiosity", in Terpstra (ed.), Confraternities and Social Order: The pre 1347 statute of San Ruffino of Assisi: "Item quilibet fugiat ut pestem mortiferam longa colloquia et consortia mulierum que prestant et inferunt causam libidinis et hosticulum inhonestatis" (at note 31).

${ }^{8}$ Gilles Gerard Meersseman, Ordo Fraternitatis: Confraternite e pietà dei laici nel medioevo 3 vols., Italia Sacra vols. xxiv-xxvi, Rome: Herder, 1977, vol. 1, pp.500-501; Lester Little, Libertà, Fraternità. Confraternite laiche a Bergamo nell'età del comune. Bergamo, 1988, p. 204; Casagrande, "Confraternities as a vehicle for women's religiosity".

${ }^{9}$ Flagellant nomenclature and flagellating did not necessarily preclude women members, though the communal activity involving a degree of nudity might essentially be a male-bonding operation.

${ }^{10}$ Black, Italian Confraternities, pp. 34-38; L. Scaramucci, "Considerazioni sui statuti e matricoli di Confraternite dei Disciplinati”, in AA.VW. Risultati e Prospettive della ricerca sul movimento dei disciplinati [Convegno Internazionale di Studio. Perugia, 1969], Perugia: Centro di documentazione sul movimento dei disciplinati, 1972, p. 150; Terpstra, Lay Confraternitieses, pp. 84, 126-30; Casagrande, "Confraternities as a vehicle", at notes 62-67. Louis A.Waldman, "The 'Master of the Kress Landscapes' unmasked: Giovanni 
Larciani and the Fucecchio altar-piece", The Burlington Magazine, 140:1144 (July 1998), pp. 457-469. The painting, in the Museo Civico is The Nativity with Saints Michael, Clement, Martha and Peter, with a lunette showing The Trinity and the Evangelists. Three contracts dealing with this commission survive; the price was subject to appraisal on completion and is not known. The three women officials signing the contracts also paid part of the cost, though others (including males), also contributed. The sorority, based in the Franciscan church of San Salvatore, was given various other names including, Societas Mulierum Beate Virginis Marie, and Compagnia delle Donne. The town also had an all-male Compagnia della Vergine della Croce, with its own oratory near San Salvatore. The female society seems to have ceased to exist between 1583 and 1588 .

${ }^{11}$ Anna Esposito, "Men and Women in Fifteenth Century Roman Confraternities: Roles, Devotional Aims, Expectations", forthcoming in Terpstra (ed.), Confraternities and Social Order.

${ }^{12}$ Jennifer Rondeau, "Homosociality and civic (dis)order in late medieval Italian confraternities", in Terpstra (ed.), Confraternities and Social Order. Rondeau, "Prayer and Gender in the Laude of Early Italian Confraternities", in Richard Trexler (ed.), Gender and Rhetorics. Postures of Dominance and Submission in History. Binghampton N.Y.: State University of New York, 1994, esp. pp. 228-33. One assumes that the admission of women for caring roles in hospital-linked confraternities such as those mentioned by Anna Esposito, might similarly have affected the devotions, but this remains to be clarified. For women and confraternities more widely see: Casagrande, "Women in Confraternities", which is useful for more than Umbria; Ludovica Sebregondi, “A Confraternity of Florentine Noble Women”, Confraternitas, 4:2 (Fall 1993), pp. 3-6; Nicholas Terpstra, "Women in the Brotherhood: Gender, Class and Politics in Renaissance Bolognese Confraternities", Renaissance and Reformation, 26 (1990), pp. 193-212; Black, Italian Confraternities, pp. 34-38, 103-4; Danilo Zardin, Confraternite e vita di Pietà nelle campagne lombarde tra ‘500 e '600. Milan: Nuove Edizioni Duomo, 1981.

${ }^{13}$ Black, Italian Confraternities, pp. 39-41; Ronald Weissman, Ritual Brotherhood in Renaissance Florence. New York and London: Academic Press, 1982, pp. 202-5; Richard C.Trexler, Public Life in Renaissance Florence. New York and London: Academic Press, 1980, pp. 407, 411-14. Some issues about the similarities and differences between guilds and fraternities, especially in the later part of our period, are raised in a new collection of essays: Alberto Guenzi, Paola Massa and Fausto Piola Caselli (eds.), Guilds, Markets and Work Regulations in Italy, 16th-19th Centuries. Aldershot and Brookfield USA: Ashgate, 1998; see esp. Carlo Maria Travaglini, "The Roman Guilds System in the Early Eighteenth Century", pp. 150-70, and Luigi Mascili Migliorini, "Brotherhoods and Guilds in Naples in the Eighteenth Century: Religious Devotion and the Protection of Crafts", pp. 395-408.

${ }^{14}$ Interestingly this had also applied in Geneva: Louis Binz, "Les confréries dans le diocèse de Genève", Le Mouvement Confraternel au Moyen Age. France, Italie, Suisse. Rome: École Française de Rome, 1987, pp. 233-61, esp.p. 245.

${ }^{15}$ By 1415 this was more centrally located in San Bartolomeo at the Rialto: R.Mackenney, "Continuity and Change in the scuole piccole of Venice, c. 1250-c. 1600", Renaissance Studies, 8 (1994), pp. 388-402, esp. pp. 400-1; and his forthcoming "The scuole piccole of Venice: formations and transformations", in Terpstra (ed.), Confraternities and Social Order, at n. 31.

${ }^{16}$ On Venice the various works by Richard Mackenney: Tradesmen and Traders. The World of the Guilds in Venice and Europe C. 1250-c. 1650. London \& Sydney: Croom Helm, 1987, esp. ch. 2; "Guilds and Guildsmen in sixteenth-century Venice", Bulletin of the Society of Renaissance Studies, 2:2 (October 1984), pp. 7-12; "Continuity and Change in the scuole piccole of Venice, c. 1250-c. 1600"; "Public and private in 
Renaissance Venice", Renaissance Studies, $12: 1$ (March 1998), pp. 109-30; "The Scuole Piccole" of Venice: Formation and Transformations". A valuable recent overview of the Venetian scuole in their many forms and with varied roles is provided by Patricia Fortini Brown, "Le 'Scuole' "in Storia id Venezia dalle origini alla caduta della Serenessima, vol. V: II Rinascimento. Società ed Economia. Rome: Istituto della Enciclopedia Italiana, 1996, pp. 307-54. See also Black, Italian Confraternities, pp. 39-40; Edoardo Grendi, “Morfologia e dinamica della vita associativa urbana. Le confraternite a Genova fra i secoli xvi e xviii”, Atti della Società Ligure di Storia Patria, 79:2 (1965), pp. 239-311.

${ }^{17}$ Archivio di Stato, Rome, Camerale II, Arti e Mestieri: Busta 6, Bombardieri di Castello and Caffetieri (foglio 12); Busta 25, Muratori, Stoccatori, Imbiancatori, and Musicanti (foglio 56); Busta 19, Lanari. These records and others show that guilds as well as confraternities could be awarded a papal privilege of being able to petition for the release of prisoners. Surviving petitions sampled usually indicate that the prisoner had made peace with the victim's family, and that his pardon would allow him to help his own family. The petitioning fraternity might receive some financial as well as spiritual reward for their good work. See Black, Italian Confraternities, pp. 219-22. On Roman guilds and fraternities see now the article by Carlo M.Travaglini, 'The Roman Guilds System', cited above in note 13. In the same collection of essays Angelo Groppi, 'Jews, Women, Soldiers and Neophytes: The Practice of Trades under Exclusions and Privileges (Rome from the Seventeenth to the Early Ninteenth Centuries', pp. 372-92, looks at the guild of tailors and its related confraternity, Confraternita de' Sarti nella Chiesa di S.Omobono, and the way the tailors sought to preserve their identity; while "other" groups including women, Jews and converts sought their identities and protection systems.

${ }^{18}$ Black, Italian Confraternities, pp. 45-6, 174; Grendi, “Morfologia”.

${ }^{19}$ But officially recognised only in 1553 ?

${ }^{20}$ Lance Lazar, "The First Jesuit Confraternities and marginalized groups in sixteenth-century Rome," in Terpstra (ed.), Confraternities and Social Order; he notes similar houses existing by 1551 in Agrigento, Bologna, Palermo, Trapani, Messina, Modena, Padua, Florence, Casola in Lunigiana, and Venice. See also on Jesuits, Black, Italian Confraternities, p. 46; Mario Rosa, "Geografia e storia religiosa per I' 'Atlante Storico Italiano'", Nuova Rivista Storica, 53 (1969), pp. 1-43; John W. O'Malley, The First Jesuits. Cambridge Mass and London: Harvard University Press, 1993, pp. 166, 192-9.

${ }^{21}$ Black, Italian Confraternities, pp. 176-7; L. Cajani, "Gli statuti della Compagnia dei Ciechi, Zoppi e Stroppiati della Visitazione (1698)", Ricerche per la Storia Religiosa di Roma, 3 (1979), pp. 281-313, esp. pp. 281-90, 297; Brian Pullan, "Poveri, mendicanti e vagabondi”, in Storia d'Italia. Annali 1. Dal feudalismo al capitalismo. Turin: Einuadi, 1978, p. 990.

${ }^{22}$ Black, Italian Confraternities, pp. 43-45; Armando Serra, "Funzione e formazione delle confraternite romane tra il 1624 a il 1797", Ricerche per la Storia Religiosa di Roma, 5 (1984), pp. 261-92, esp. p. 269 , note 25; James Ball, "Poverty, charity and the Greek community", Studi Veneziani, 6 (1982), pp. 129-45; Silvana di Mattia Spirito, "Assistenza e carità ai poveri in alcuni statuti di confraternita nei secoli xv-xvi", Ricerche per la Storia Religiosa di Roma, 5 (1984), pp. 137-154, esp. p. 142: the 1544 statutes of San Giovanni Battista della Pietà dei Fiorentini in Rome wanted to include all Florentines, "vogliamo che si possa accettare nella nostra compagnia nobili, ignobili, ricchi, poveri, uomini, donne, giovani, vecchi et finalmente ogni ragion di persone." On the Spanish confraternity, besides his talk to this Seminar, see Thomas Dandelet, "Spanish Conquest and Colonization at the Center of the Old World: The Spanish Nation in Rome, 1555 1625", Journal of Modern History, 69 (1997), pp. 479-511. 
${ }^{23}$ ASR Cam. II. Arti e Mestieri, Busta 25, foglio 57, "Norcini”, and Busta 33 "Pizzicaroli”; Patrick Barbier, The World of the Castrati. The History of an Extraordinary Operatic Phenomenon, translated by Margaret Crosland. London: Souvenir Press, 1996, pp. 27-28, though admitting that Norcia's reputation as a castration capital might have been exaggerated

${ }^{24}$ Archivio di Stato, Venice [hereafter ASVen] Sant'Uffizio, Processi, busta 61, folder entitled; "Verseman Giovanne e compagne". It is interesting to contrast this with a pre-Reformation German experience, with that of the German Confraternity of St. Barbara in Siena, that commissioned a major altarpiece in 1478 in the Dominican church. Here German brothers (including Flemings) working in textiles, but also being swordmakers, taverners, cooks, bakers, tanners etc., sought to rival the patrician Borghesi family that patronised the neighbouring chapel; see Max Seidel, 'The social status of patronage and its impact on pictorial language in fifteenth century Siena', in Eve Borsook and Fiorella Superbi Giofreddi (eds.), Italian Altarpieces 12501550. Function and Design. Oxford: Clarendon Press, 1994, pp. 119-37.

${ }^{25}$ ASVen, Sant'Uffizio, Busta 66, folder entitled "S.Giovanni, (Confraternite)". The delator, or accuser, was Bernardino de Ferris, rassarius. For the Florentine buche fraternities, and the stress that they were not necessarily underground meetings as sometimes alleged, see Konrad Eisenbichler, The Boys of the Archangel Raphael. A Youth Confraternity in Florence, 1411-1785. Toronto: Toronto University Press, 1998, pp. 23, 348 note 2, 349 note 7. Cf. Ludovica Sebregondi, Tre confraternite fiorentine: Santa Maria della Pietà, detta "Buca" di San Girolamo, San Filippo Benizi, San Francesco Poverino. Florence: Salimbeni, 1991.

${ }^{26}$ Black, Italian Confraternities, pp. 268-9; Brian Pullan, “'A Ship with Two Rudders': Righetto Marrano and the Inquisition in Venice", The Historical Journal, 20 (1977), pp. 25-58. Pullan (p. 35), indicates that there was hearsay evidence from one witness that some members of the Ribeiro family took communion bread, but dashed away to spit it out or sick it up; this was denied by another witness and not further investigated. Righetto attended sermons and mass, but did not receive the host. Chaim Baruch, consul of the Levantine Jews had said: "I took that Gaspare [Ribeiro] for a Marrano, and we think of Marranos as ships that have two rudders"..., "For a ship to have two rudders means that with one rudder it sails with one wind, and with the other with another wind." (Pullan, p. 37). See also on the Ribeiro family, Pullan, The Jews of Europe and the Inquisition of Venice 1550-1670. Oxford: Blackwell, 1983, esp. pp. 230-41. According to the papal Nunzio in Venice, Alberto Bolognetti, who took considerable interest in the case, the family troubles came before the Venetian legal authorities because Gaspare refused to pay the dowry to the Jewish girl (Alumbra) whom João (Giovanni) had secretly married; Alumbra claimed the dowry on Giovanni's death after four years of marriage. Civil litigation before the Avogadori di Commun was brought to the attention of the Holy Office at Bolognetti's insistence and contrary to the wishes of the Avogadori; see Aldo Stella, Chiesa e Stato nelle relazioni dei Nunzi Pontifici. Ricerche sul giurisdizionalismo veneziano dal xvi al xviii secolo. Città del Vaticano: Biblioteca Apostolica Vaticana, 1964, pp. 136-7, 289.

${ }^{27}$ Black, Italian Confraternities, p. 41; Vincenzo Paglia, 'La Pieta dei Carcerati': Confraternite e Società dei Carcerati a Roma nei secoli xvi-xvii. Rome: Edizioni di Storia a Letteratura, 1980, pp. xi, 46, 87, 106-9.

${ }^{28}$ The interaction of confraternity and parish is developed in my "Confraternities and the Parish in the context of Italian Catholic Reform", now published in J. Patrick Donnelly and Michael W. Maher (eds.), Catholic Reform in Italy, France, and Spain, Kirksville. Missouri: Thomas Jefferson University Press, 1999, Sixteenth Century Essays \& Studies, volume 44, pp. 1-26. Some of the detail here repeats what is in that delayed publication, and some is new. 
${ }^{29}$ Mario Fante, "La Parrocchia dei SS.Vitale e Agricola dal Medioevo al Settecento," extract from Gina Fasoli (ed.), Vitale e Agricola. I/ Culto dei protomartirie di Bologna attraverso / secoli. Bologna: Edizioni Dehoniane, 1993, pp. 217-47, esp. pp. 225-31. Benedictine nuns had some residual patronage rights, which may help explain the balance of 140 women to 128 males in the opening membership lists. The painter Prospero Fontana (father of the now more famous woman painter Lavinia), and architect Bartolomeo Triachini were members. In 1693 poor relief organised by this fraternity went to 487 parishioners.

${ }^{30}$ John Martin, Venice's Hidden Enemies. Italian Heretics in a Renaissance City. Berkeley, Los Angeles and London: University of California Press, 1993, pp. 191-4; Weissman, Ritual Brotherhood, pp. 215-20.

${ }^{31}$ Biblioteca del Museo Correr, Venice. Mariegole no. 195, Mariegola degli strazzaruoli (1430-1633), fols. 200-04; a transcript of which was kindly provided by Patricia Allerston, now of Edinburgh University, who unearthed it while researching for her Doctorate for the European University Institute in Florence, "The Market in Second-Hand Clothes and Furnishings in Venice, c.1500-c. 1650" (1996). The thesis, which is being revised for publication, is an important insight into the complexities of second-hand dealing as a significant part of an urban economy involving all levels of society. For some already published insights and examples, see her articles "Wedding finery in sixteenth-century Venice, "in Trevor Dean and K.J.P.Lowe (eds.) Marriage in Italy, 1300-1650. Cambridge: Cambridge University Press, 1998, pp. 25-40; "Le marché de l'occasion à Venise aux xvie - xviie siècles", in Jacques Bottin and Nicole Pellegrin (eds.) Échanges et culture textiles dans L'Europe pré-industrielle. Lille: Revue du Nord, 1996, pp. 15-29.

${ }^{32}$ Zardin, Le confraternite e vita di pietà, pp. 54-7; Carla Russo, Chiesa e communità nella diocesi di Napoli tra Cinque e Settecento vol. 2. Naples: Guida Editore, 1984, pp. 315-20; Marina Olivieri Baldissarri, I 'Poveri prigioni'. La confraternita della Santa Croce e della Pietà dei Carcerati nei secoli XVI - XVIII. Milan: Nuove Edizioni Duomo, 1985, pp. 199-216, 223-31; Black, Italian Confraternities, pp. 235-7; Elena Fasano Guarini (ed.), Prato storia di una città, 2: Un microcosmo in movimento (1494-1815). Prato: Le Monnier, 1986, pp. 540-1; Gaetano Greco, La parrocchia a Pisa nell'età moderna (secoli xvii-xviii). Pisa: Pacini editore, 1984, pp. 77-80. See also my "Confraternities and the Parish" (1999), with further references and examples of the balance of power and influence between fraternities and parochial clergy, respective advantages and disadvantages in their relationships.

${ }^{33}$ ASVR, SS. Sacramento e Cinque Piaghe in San Lorenzo in Damaso. Decreti delle Congregazioni, 155084; cf. "Repertorio degli Archivi delle Confraternite Romane," Ricerche per la Storia Religiosa di Rome, 6 (1985), pp. 175- 430, at pp. 372-3. The archive is not properly inventoried; most material surviving seems to come from the eighteenth and nineteenth centuries. An inventory of the sacristy's holdings in 1550 , valued in total at 598 ducats, included two gold and silver tabernacles worth 30 and 33 ducats, a gilded large silver chalice and silver pattern worth 15 ducats; and some unvalued and unattributed paintings including an Annunciation, Christ Carrying the Cross, Christ on the Cross, Madonna and Child, and a Christ painted on taffetta used when carrying corpses, (Decreti, fols.2r-3r). As many as 63 persons were registered as attending the general congregation in 1580 (fols.54v-55r). Women were elected as infermieri but did not seem to help in selecting girls suitable for the dowries. In 1558 on the preference for dowries "dopo molte ragioni, fu concluso che se ne maritino tredeci le piu pouere di eta di anni sedici in su et che sopra tutto 0 loro siano del Compagnia o decesi da li fratelli o sorelle de la Compagnia" (fol.23v); in later years the numbers of dowries offered went up to 21 (fol.30r, 1560), then 27 (fol.72v, 1582).

${ }^{34}$ ASVR, Congregazione del Soccorso de'Poveri in San Lorenzo in Damaso, palchetti 168- 170. See especially Atti Ufficiali, Congregazioni e decreti, vol. 3 (1602-10), vol. 4 (1617- 29); Elemosine, Elenco dei 
Poveri. Vol. 30 (1624-25); Entrate e Uscite, vol. 12 (1622-28). Active from 1602 the Soccorso was given papal approval in 1603. Most surviving material is from the $17^{\text {th }}$ and $18^{\text {th }}$ centuries. Paola Baroncini has provided a modern inventory; and see "Repertorio degli Archivi", pp. 407-8. Fiorenza Gemini, "Aspetti sociali e religiose della parrocchia di San Lorenzo in Damaso in Settecento" Ricerche per la Storia Religiosa di Roma, 4 (1980), pp. 149-74.

${ }^{35}$ ASVR Congregazioni vol. 3, April 9, 1610; vol. 4, Nov. 20, 1626; Elenco dei Poveri, vol. 30, 1624 \{1627\}: "Dorotea zitella inglese nel vic.o [vicolo] di Corte Savella" was given holy oil on September 11, 1624, but she died on the $12^{\text {th }}$, without having had her confession heard; entries for the Germans in the hospital in August 1625 .

${ }^{36}$ ibid., vol.4, 14 Jan.1628 (entry copied from a document sealed in the Apostolic Chancellery the day before); eight capitoli are imposed on both sides. For the Soccorso's benefit, they were guaranteed a rent income from a house used by the Confessors, and the latter had to say a daily mass imposed on the congregation by a legacy. The titular Cardinal provided much of the income: about 1800 out of 2900 scudi a year in the 1620s. The College of Confessors, instituted by Cardinal Montalto in 1611 to ensure regular confessions, and to assist the poor, was usually made up of six secular priests; seemingly they often diverted the income to their own purposes, Gemini, "Aspetti sociali", pp. 168-73.

${ }^{37}$ ASVR, loc.cit., Congregazioni, vol.4 , 12 March 1629. The painter Giulio de Bonis was paid 4 scudi for an unspecified picture; Giuseppe Buglia 10 scudi for a picture of a Seraphim; Pietro Baciano, the festaiolo, was given 12 scudi for the apparato (i.e. some kind of scenic backdrop), and Balthassare, carpenter, $16.50 \mathrm{sc}$. for erecting it; Sig. Giovanni Giacomo, maestro di capella was paid 25 scudi for the music for the Quarantore. San Lorenzo was notable for Quarantore celebrations which might involve major artists like Pietro da Cortona as in 1633; see Black, Italian Confraternities, pp. 99-100, 272; Christopher Black, "'Exceeding every expression of words': Bernini's Rome and the Religious Background", in Aidan WestonLewis (ed.), Effigies \& Ecstasies: Roman Baroque Sculpture and Design in the Age of Bernini. Edinburgh: National Gallery of Scotland, 1998, pp. 11-21, esp. pp. 19-20, and catalogue no. 126, pp. 162-3, for Pietro da Cortona's design; Renato Diez, "Le Quarantore: Una predica figurata”, in Marcello Fagiolo (ed.), La Festa di Roma. Rome, 1997, vol. II, pp. 84-97. The long officiating depositor Carlo Ghezzi seems to have a major interest in sponsoring Christian Doctrine teaching.

${ }^{38}$ Each section had its own statutes, guiding the different spiritual practices under different officials. The argument at the time (as made in the confraternity of Santa Maria della Vita, which also ran a hospital) was that they were Pauline in having many functions within an unbroken community. The stretta members belonged to the larga, and in Terpstra's view acted as a conscience for the whole brotherhood. However tensions developed between the groups. In some cases larga membership came to mean little in devotional terms (with women losing out here), while the activity was mainly connected with the hospital institutions. Santa Maria della Morte developed an elite group (from largely the patrician elite) to act as comforters of prisoners, a Scuola dei Confortatori. By 1556 this was a clearly distinguished group, with own statutes, officials and finances. They developed specialist techniques in encouraging prisoners' confessions, declarations of repentance, and acceptance of the death sentence. See Terpstra, Lay Confraternities, pp. 139-144; Terpstra, "Confraternal Prison Charity and political consolidation in sixteenth-century Bologna", Journal of Modern History, 66 (1994), pp. 217-48. Daniel Bornstein in a Review of Terpstra's book questions the argument about increased patrician dominance, suggesting that Terpstra has built too much on the basis of an increased use of surnames, when by the 16th century they should not be used as a test 
of "patrician", when family names were used further down the social hierarchy: Speculum, 73:2 (April 1998), pp. 605-7. With the Confortatori seemingly increasingly staffed by the Bologna social elite it could lead to the accusation that they thus served an elitist law and order policy more than the welfare of the poor prisoner. Addendum, June 1999: an interesting discussion of larga/stretta divisions, this time in a Modena fraternity, now comes from Michelle M. Fontaine, "A House Divided. The Compagnia de Danta Maria dei Battuti in Modena on the Eve of Catholic Reform," in Donnelly \& Maher (ed.), Confraternities and Catholic Reform, pp. 55- 73.

${ }^{39}$ Marina Olivieri Baldissarri, “I Poveri prigioni”, esp. pp. 103-5, 114-16, 225-6.

${ }^{40}$ Konrad Eisenbichler, The Boys of the Archangel Raphael.

${ }^{41}$ Black, Italian Confraternities, pp. 46-47, Bologna's Corpo di San Procolo has the longest list of the excluded (p.46, note 78): "heretics, public or private usurers, sodomites, public concubines, adulterers, blasphemers of God and the saints, gamblers, frequenters of taverns, public controversialists [partesani], or those who practised a prohibited art, or who conversed in dishonest places or with dishonest person, or who have been a thief, or who have made incantations or charms etc."; Mario Fanti, San Procolo. Una Parrochia di Bologna dal medioevo al età contemporanea. [Bologna], 1983, p.164. Terpstra, Lay Confraternities, pp. 108-9.

${ }^{42}$ Black, Italian Confraternities, pp. 84-89; John Henderson, Piety and Charity in Late Medieval Florence. Oxford: Clarendon Press, 1994, pp. 136-140; Terpstra, Lay Confraternites, pp. 108-16; Joelle Rollo-Koster, "Death and the Fraternity. A Short Study on the Dead in Late Medieval Confraternities," Confraternitas, 9:1 (Spring 1998), pp. 3-12.

${ }^{43}$ Konrad Eisenbichler, "The Suppression of the Confraternities in Enlightenment Florence", forthcoming in Terpstra (ed.), Confraternities and Social Order; Eisenbichler, The Boys of the Archangel Raphael, pp. 297306. Issues about active and passive membership were fully faced by Weissman in his Ritual Brotherhood, and other key works have considered the problem, like Terpstra's, Lay Confraternities, Paglia's "La Pietà dei Carcerati", James R.Banker, Death in the Community. Memorialization and Confraternities in an Italian Commune in the late Middle Ages. Athens, Ga: University of Georgia Press, 1988. Eisenbichler's The Boys of the Archangel Raphael. But none has been able to provide a social analysis of membership overall, or of the active elements and their wider influences in society. 